TERRA. Revista de Desarrollo Local e-ISSN: 2386-9968

Número 7 (2020), 24-47

DOI 10.7203/terra.7.17239

IIDL - Instituto Interuniversitario de Desarrollo Local

\title{
Inner peripheries: dealing with peripherality and marginality issues within the European policy framework
}

\author{
Andrea De Toni \\ PhD. Dpt. di Bioscienze e Territorio, Università degli Studi del Molise (Isernia, Italy), \\ and Dpt. of Architecture and Urban Studies, Politecnico di Milano (Milan, Italy) \\ andrea.detoni@polimi.it - https://orcid.org/0000-0002-3573-7585
}

\section{Matteo Vizzarri}

PhD. European Commission, Joint Research Centre (Ispra, Italy) matteo.vizzarri@ec.europa.eu - https://orcid.org/0000-0002-9505-783X

\section{Bruno Lasserre}

Prof. Dpt. di Bioscienze e Territorio, Università degli Studi del Molise (Isernia, Italy) lasserre@unimol.it -https://orcid.org/0000-0003-1150-8064

\section{Giovanni Carrosio}

PhD. Dpt. of Political and Social Sciences, University of Trieste (Trieste, Italy) gcarrosio@units.it - https://orcid.org/0000-0003-2402-2645

\section{Lorenzo Sallustio}

PhD. Dpt. di Bioscienze e Territorio, and Research Centre for Inner Areas and Apennines, Università degli Studi del Molise ((Isernia \& Campobasso, Italy) lorenzo.sallustio@unimol.it - https://orcid.org/0000-0001-9204-5123

\section{Paolo Di Martino}

Prof. Dpt. di Bioscienze e Territorio, Università degli Studi del Molise (Isernia, Italy) dimartin@unimol.it -https://orcid.org/0000-0001-8853-7520

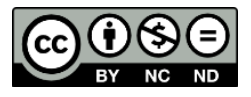

Esta obra se distribuye con la licencia Creative Commons Reconocimiento-NoComercial-SinObraDerivada 4.0 Internacional 


\title{
SECCIÓN ARTÍCULOS
}

\author{
Inner peripheries: dealing with peripherality and marginality issues within the European policy \\ framework
}

\begin{abstract}
Inner Peripheries is a complex and often misinterpreted concept, as demonstrated by current scientific evidence. Such complexity derives from the intrinsic peripherality and marginality characteristics of the Inner Peripheries. Despite Inner Peripheries suffer from geographical and socio-economic disparities, their environmental, social and economic potentialities are not fully expressed, and thus can be further strengthened by both the EU Cohesion and Rural Development Policies. However, there is currently a lack of knowledge about the linkages between the Inner Peripheries and both Cohesion and Rural Development Policies, which could limit the effectiveness of planning strategies in these territories. Therefore, through a structured review, we explore the linkages between Inner Peripheries and peripherality and marginality concepts and related criticalities and opportunities. Moreover, we consider the relationships between Inner Peripheries and Cohesion Policy Thematic Objectives and Rural Development Policy Priorities. The main findings show that the Inner Peripheries concept needs to be further explored, especially concerning the environmental aspects. Accordingly, we suggest that great challenges and opportunities currently exist in these territories, and combined policies efforts need to be oriented to strengthen the future sustainable development in the Inner Peripheries..
\end{abstract}

Key words: Review, Rural Development Policy, Cohesion Policy, Inner Areas. Inner peripheries: abordando los problemas de periferia y marginalidad en el marco de la política
europea

Resumen: Inner Peripheries es un concepto complejo y a menudo mal interpretado, como lo demuestran las pruebas científicas actuales. Tal complejidad deriva de sus intrínsecas características de periferia y marginalidad. A pesar de que las Inner Peripheries sufren de disparidades geográficas y socioeconómicas, sus potencialidades ambientales, sociales y económicas no se expresan completamente y, por lo tanto, pueden ser reforzadas por las Políticas de Cohesión y Desarrollo Rural de la UE. Sin embargo, actualmente existe una falta de conocimiento sobre los vínculos entre las Periferia Interior y las Políticas de Cohesión y Desarrollo Rural, lo que podría limitar la efectividad de las estrategias de planificación en estos territorios. A través de una revisión estructurada, exploramos los vínculos entre las Inner Peripheries y los conceptos de periferia y marginalidad y las críticas y oportunidades relacionadas. Además, consideramos las relaciones entre las Inner Peripheries y los objetivos temáticos de la Política de Cohesión y las Prioridades de la Política de Desarrollo Rural. Los principales hallazgos muestran que el concepto de Inner Peripheries necesita ser explorado más a fondo, especialmente en relación con los aspectos ambientales. Sugerimos que actualmente existen grandes desafíos y oportunidades en estos territorios, y que los esfuerzos de políticas combinadas deben orientarse para fortalecer el desarrollo sostenible futuro en las Inner Peripheries.

Palabras clave: Revisión; Política De Desarrollo Rural; Política De Cohesión; Áreas Internas.

Recibido: 29 de abril de 2020

Devuelto para revisión: 22 de mayo de 2020

Aceptado: 30 de junio de 2020

Referencia / Citation:

De Toni, A., Vizzarri, M., Lasserre, B., Carrosio, G., Sallustio, L., and Di Martino, P. (2020). Inner peripheries: dealing with peripherality and marginality issues within the European policy framework. TERRA: Revista de Desarrollo Local, (7), 24-47. DOI 10.7203/terra.7.17239 
1. Inner Peripheries es un concepto complejo debido a sus características territoriales de periferia y marginalidad.

2. Las disparidades territoriales limitan los potenciales ecológicos y socioeconómicos de las Inner Peripheries.

3. En este trabajo exploramos las características de Inner Peripheries de acuerdo con políticas europeas de cohesión y desarrollo rural.

4. Hay espacio para fortalecer aún más los potenciales ambientales y territoriales de las Inner Peripheries.

5. Se proporcionan ideas y sugerencias sobre cómo fomentar el desarrollo sostenible en las Inner Peripheries.
1. Inner Peripheries is a complex concept due to its peripherality and marginality characteristics

2. Territorial disparities limit the ecological and social-economic potentials of Inner Peripheries.

3. The Inner Peripheries' features are explored in light of European cohesion and rural development policies.

4. There is room to further strengthen environmental potentials of Inner Peripheries.

5. Insights and suggestions on how to foster sustainable development in Inner Peripheries are provided.
1. Inner Peripheries és un concepte complex a causa de les seues característiques territorials de perifèria i marginalitat.

2. Les disparitats territorials limiten els potencials ecològics i socioeconòmics de les Inner Peripheries.

3. En aquest treball explorem les característiques de Inner Peripheries d'acord amb polítiques europees de cohesió i desenvolupament rural.

4. Hi ha espai per a enfortir encara més els potencials ambientals i territorials de les Inner Peripheries.

5. Es proporcionen idees i suggeriments sobre com fomentar el desenvolupament sostenible en les Inner Peripheries. 


\section{INTRODUCTION: INNER PERIPHERIES AS A RECENT CONCEPT}

The Inner Peripheries concept has been recently interpreted as coupling peripherality and marginality concepts (Copus, Mantino, \& Noguera, 2017; Noguera \& Copus, 2016). The debate around such terms focuses on the polarization of space, as argued by several authors (e.g. Máliková \& Klobučník 2017; Kebza 2018). Theoretically, there are centres (namely, core areas), that have a high degree of autonomy and potential for creating innovation and growth, and peripheries, that are dependent on centres (Friedmann, 1966). The terms peripherality and marginality are consistent with this theory, and still debated in literature, as well as their respective processes (Kühn, 2015; Pezzi \& Urso, 2017). In particular, primarily the peripheralization and secondarily the marginalization processes generate the stigmatization process (ESPON, 2017), and subsequently, poverty and outmigration. Such dynamics ultimately generate both peripherality and marginality that are common conditions of the Inner Peripheries. In fact, "the peripherality of an area is connected with spatial (situational) characteristics such as distance and transport accessibility. Marginality, on the other hand, is shaped by a "multi-dimensional" spectrum of problems, from economic and cultural to social, political and historical" (Pileček \& Jančák 2011, p.45).

More specifically, according to ESPON 2017, the peripherality is characterized by a lack of innovation and powerlessness (exclusion from network and lack of agency), in addition to the distance from core areas (Kühn, 2015) and poor accessibility. The marginality is described by different approaches that explain multifaceted problems, such as (Pileček \& Jančák, 2011): (i) the geometric approach, underlining the remoteness of an area; (ii) the ecological approach, representing the environmental conditions (e.g. an area as biodiversity hotspot); (iii) the social approach, referring to a weak integration of social groups because of ethnicity, gender, religion, etc. (including cultural marginality); (iv) the economic approach, focusing on the regional economic disparities (economic activities, Gross Domestic Product, etc.); and (v) the political approach, considering the distance from the centres of power. According to these characteristics, the marginality and peripherality concepts are strictly interconnected (Nagy, Timár, Nagy, \& Velkey, 2015).

In EU, the Inner Peripheries concept is a quite new theme, originally coined by ESPON (2013a), and referred to territories suffering from: (i) demographic decline (migration and low birth rates), population ageing, lack of Services of General Interest (SGIs) such as hospitals and schools, lack of accessibility (time), lack of economic diversity, loss of local identity; (ii) restricted development areas/zoning, closing down of main economic activities and of SGIs; and (iii) closeness (proximity) to natural barriers. For example, there was a first attempt in Italy to define territories characterised by distance from SGIs (i.e. Inner Areas) (Barca, Casavola \& Lucatelli 2014), resulting in a sub-category of Inner Peripheries. Finally, the Inner Peripheries' broad definition was further explored and improved by ESPON (2017). Indeed, according to the latter definition, Inner Peripheries are characterized by poor accessibility to core areas and to SGIs, as well as the exclusion from networks, which in turn lead to negative demographic trends, social exclusion and economic decline (Copus et al., 2017). Such different definitions of Inner Peripheries and Inner Areas have increasingly led to a terminological confusion, at least in the scientific community.

However, the will to provide an unambiguous definition of the Inner Peripheries most probably derives from a widespread condition of unbalanced territorial development as 
perceived all around Europe. Indeed, the Inner Peripheries cover $45 \%$ of total area in Europe (ESPON 2017). It is therefore important to assess the main characteristics and issues of the Inner Peripheries to tackle challenges such as e.g. outmigration and economic decline. More than one third of the Inner Peripheries overlaps the Lagging Regions (ESPON, 2017) and about 80\% of rural areas in Europe (ESPON, 2018). This in turn means that the Cohesion Policy, directly related to Lagging Regions, and the Rural Development Policy, mainly sustaining the agricultural areas, are by-nature in support of the Inner Peripheries. Beyond all the disadvantages previously listed, the Inner Peripheries have resources that may be sustainably used through the EU funds. For example, in Italy these territories are mainly covered by forest lands, agricultural areas and Protected Areas (Marchetti, De Toni, Sallustio, \& Tognetti, 2017), and are characterized by the presence of the primary sector, and by a predisposition towards social innovation (Carrosio, 2016).

These characteristics and the related development potential, are consistent with the 11 Thematic Objectives (Cohesion Policy) or 6 Priorities (Rural Development Policy) scopes and targeted investments. The Thematic Objectives of the Cohesion Policy generally focus on the enhancement of the enterprises competitiveness and infrastructure network, the promotion of resource efficiency and environmental conservation, and the improvement of sustainable employment, institutional capacity and social inclusion. The Priorities of the Rural Development Policy are focused on the development of the agroforestry sector, the improvement of farm viability and competitiveness and of the food chain, as well as the ecosystem restoration and climate change adaptation and mitigation. However, for example Barca (2012) indicates the Inner Peripheries as strategic territories to effectively orient and use the EU Cohesion Policy funds. Nevertheless, to date the potentiality of Inner Peripheries to boost local economic development (through Rural Development Policy funds) is rather unexpressed (Cesaro \& Marongiu, 2017).

According to the above-mentioned issues, the present work mainly aims to understand the Inner Peripheries status quo in Europe, in terms of the main issues and challenges linked to peripherality and marginality characteristics, including their linkage with Cohesion and Rural Development policies, through an extensive review of currently available scientific literature. We deeply focus on how peripherality and marginality concepts are addressed in the context of the Inner Peripheries, and to what extent the Thematic Objectives of the Cohesion Policy as well as the Priorities of the Rural Development Policy are connected to the Inner Peripheries in Europe.

\section{REVIEW EXERCISE}

In a preliminary step, similar terms and synonyms of the Inner Peripheries concept have been identified, according to the currently available terminologies (Appendix 1). Considering that a unique definition of the Inner Peripheries does not still exist (Copus et al., 2017), we use as reference concept the latest definition of Inner Peripheries provided by ESPON (2017) (see the Introduction section for further details), because we consider it as: (i) comprehensive (incorporating both peripherality and marginality concepts and Inner Areas as an Inner Peripheries typology); (ii) most up-to-date; and (iii) evidencebased (based on territorial evidences all around Europe supporting policy-making; Böhme 2016). 
The identification of similar terms and synonyms of Inner Peripheries was needful to set the keywords that have been then used in the review exercise, and try to be as comprehensive and inclusive as possible. The similar terms are strictly connected with the Inner Peripheries because of their main characteristics, such as accessibility (i.e. Remote Rural Regions, Brezzi, Dijkstra, \& Ruiz 2011) and/or disparities in welfare state (i.e. Fragile Rural Areas; Osti 2016). The synonyms are different translations of the Inner Peripheries concept, such as for instance Inner Areas adopted in Italy (Noguera \& Copus, 2016), or even others such as Internal Areas and Inland Areas (Saccomani, 2014; Scrofani \& Novembre, 2015).

Table 1. The combination of keywords, rationale behind, and expected results. $\left({ }^{1}\right)$ The explanation of similar terms and synonyms of the Inner Peripheries concept is reported in Appendix 1

\begin{tabular}{|c|c|c|c|c|c|}
\hline $\begin{array}{l}\text { Review } \\
\text { step }\end{array}$ & $\begin{array}{l}\text { Review } \\
\text { stage }\end{array}$ & Rationale & $\begin{array}{l}\text { Research } \\
\text { database }\end{array}$ & $\begin{array}{l}\text { Keywords combination }\left({ }^{1} \text { ) }\right. \\
\text { (search strings) }\end{array}$ & $\begin{array}{l}\text { Expected } \\
\text { Results }\end{array}$ \\
\hline \multirow{2}{*}{1} & A & $\begin{array}{c}\text { Inner } \\
\text { Peripheries } \\
\text { and } \\
\text { peripherality }\end{array}$ & Scopus & $\begin{array}{l}\text { “inner peripher*” OR “remote rural } \\
\text { region*” OR “peripheral area*” OR } \\
\text { "marginal area*” OR “internal } \\
\text { peripher*” OR “inner area*” OR } \\
\text { “internal area*” OR “inland area*” } \\
\text { OR “fragile rural area*” AND } \\
\text { "peripherality” }\end{array}$ & $\begin{array}{c}\text { No. of } \\
\text { publications } \\
\text { per year }\end{array}$ \\
\hline & B & $\begin{array}{c}\text { Inner } \\
\text { Peripheries } \\
\text { and } \\
\text { marginality }\end{array}$ & Scopus & $\begin{array}{l}\text { “inner peripher*” OR “remote rural } \\
\text { region*” OR “peripheral area*” OR } \\
\text { "marginal area*” OR “internal } \\
\text { peripher*” OR “inner area*” OR } \\
\text { "internal area*” OR “inland area*” } \\
\text { OR “fragile rural area*” AND } \\
\text { "marginality” }\end{array}$ & $\begin{array}{c}\text { No. of } \\
\text { publications } \\
\text { per year }\end{array}$ \\
\hline \multirow{3}{*}{2} & C & $\begin{array}{c}\text { Inner } \\
\text { Peripheries } \\
\text { and Rural } \\
\text { Development } \\
\text { Policy }\end{array}$ & Scopus & $\begin{array}{l}\text { “inner peripher*” OR “remote rural } \\
\text { region*” OR “peripheral area*” OR } \\
\text { "marginal area*” OR “internal } \\
\text { peripher*” OR “inner area*” OR } \\
\text { “internal area*” OR “inland area*” } \\
\text { OR “fragile rural area*” AND "rural } \\
\text { development policy” }\end{array}$ & $\begin{array}{c}\text { No. of } \\
\text { publications } \\
\text { per year }\end{array}$ \\
\hline & D & $\begin{array}{c}\text { Inner } \\
\text { Peripheries } \\
\text { and } \\
\text { Cohesion } \\
\text { Policy }\end{array}$ & Scopus & $\begin{array}{l}\text { “inner peripher*” OR “remote rural } \\
\text { region*” OR “peripheral area*” OR } \\
\text { "marginal area*” OR “internal } \\
\text { peripher*” OR “inner area*” OR } \\
\text { “internal area*” OR “inland area*” } \\
\text { OR “fragile rural area*” AND } \\
\text { "cohesion policy” }\end{array}$ & $\begin{array}{c}\text { No. of } \\
\text { publications } \\
\text { per year }\end{array}$ \\
\hline & $\mathbf{E}$ & $\begin{array}{l}\text { Inner } \\
\text { Peripheries } \\
\text { and Rural } \\
\text { Development } \\
\text { Policy and } \\
\text { Cohesion } \\
\text { Policy }\end{array}$ & Scopus & $\begin{array}{l}\text { “inner peripher*” OR “remote rural } \\
\text { region*” OR “peripheral area*” OR } \\
\text { "marginal area*” OR “internal } \\
\text { peripher*” OR “inner area*” OR } \\
\text { “internal area*” OR “inland area*” } \\
\text { OR “fragile rural area*” AND “rural } \\
\text { development policy” AND “cohesion } \\
\text { policy” }\end{array}$ & $\begin{array}{c}\text { No. of } \\
\text { publications } \\
\text { per year }\end{array}$ \\
\hline
\end{tabular}

Source: authors' elaboration.

The review exercise followed two steps $(1,2)$ and five stages (A-E) (see Table 1), and was carried out through using search strings created from a combination of the keywords 
listed in Appendix 1 plus additional keywords by using SCOPUS (www.scopus.com) as search tool. The review considered title, abstract and keywords as search fields for each publication without a reference time-threshold, taking into account that the Inner Peripheries concept is relatively recent. For the purpose of the present work, and considering the characteristics of SCOPUS as search engine, we considered only the indexed and peer-reviewed publications written in English.

The step 1 of the review exercise refers to the consistency between Inner Peripheries concept and peripherality and marginality ones. The step 2 of the review exercise refers to the connection between Inner Peripheries concept and EU Rural Development and Cohesion Policies pathways. Each review step was then divided into review stages according to the main topic to be analysed. Figure 1 provides an overview of the entire review exercise.

Figure 1. Flowchart of the review exercise. From left to right, once similar terms and synonyms are identified, the review is divided into review stages ("Research design" column; stages A-E) which follow two different steps (blue and red boxes; "Research design" column) to structure the next analysis of results and related discussion (steps 1 and 2, blue and red boxes; "Review results and discussion” column)
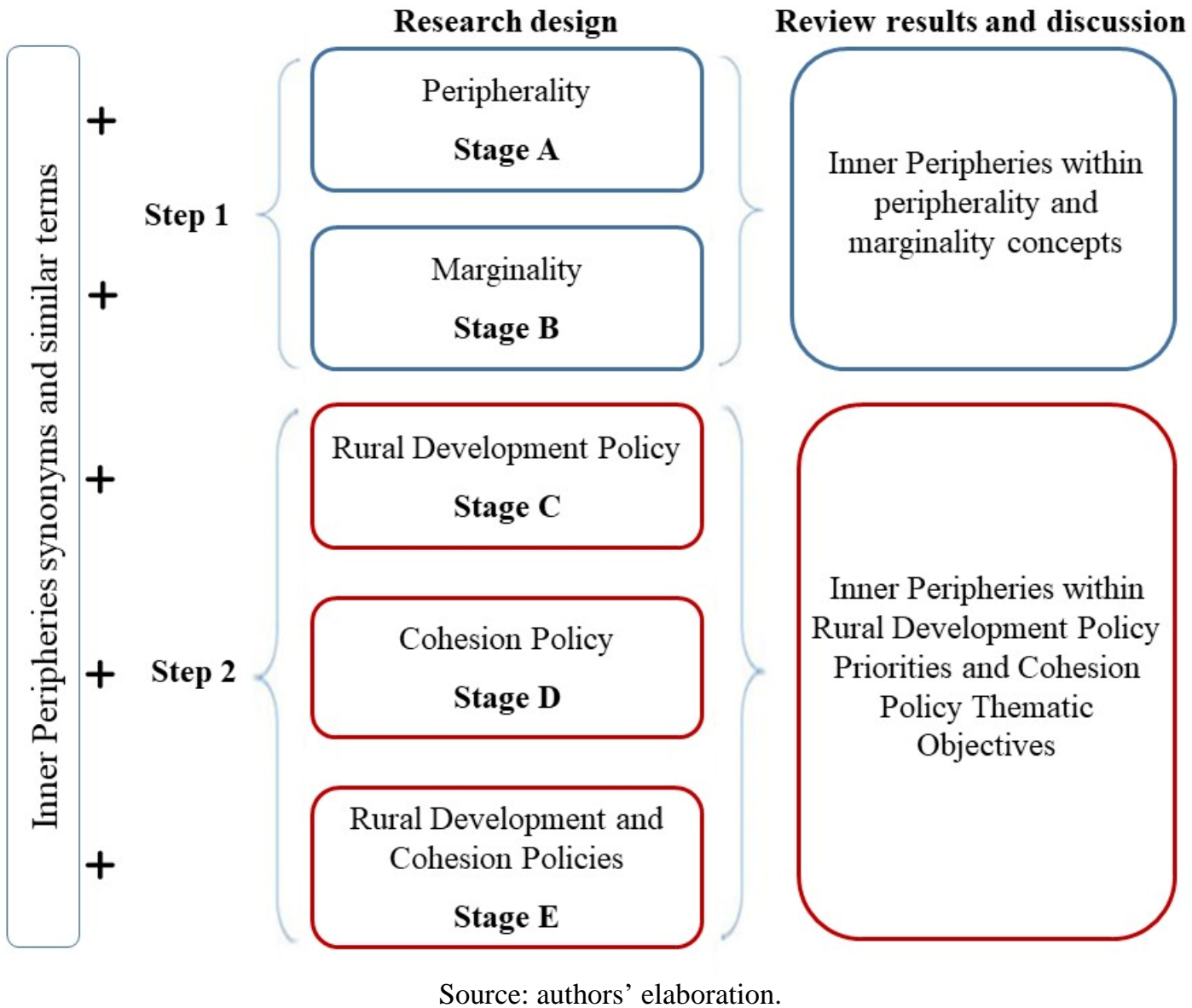

In review step 1, the following key elements for the peripherality and marginality concepts were considered: i) the relevance of peripherality for the Inner Peripheries concept - publications were classified according to their linkages with peripherality, in terms of geographical location and accessibility, lack of innovation and powerlessness (Kühn, 2015), as also described in the introduction section; and ii) the relevance of 
marginality for the Inner Peripheries concept - publications were classified according to their linkages with marginality, in terms of geometric, ecological, social, economic and political marginality (Pileček \& Jančák, 2011), as also described in the introduction section.

In review step 2, each publication was then categorized, according to i) the connection of the publication's contents with the Rural Development Policy, and particularly with one or more of its six Priorities ; ii) the connection of the publication's contents with the Cohesion Policy, and particularly with one or more of its eleven Thematic Objectives ; and iii) the connection of the publication's content and both EU Policies. In some cases, more than one specific Priority or Thematic Objective was assigned to a given publication.

\section{RESULTS}

We found a total of 70 publications to date, for both review steps 1 and 2. These results are additive, i.e. a certain publication having relevance for more than one topic, is counted twice or more. Figure 2 summarizes the publications according to the rationale (see Table 1 for further details). Inner Peripheries and marginality issue is the most debated topic (Review stage A, 35 articles), followed by Inner Peripheries and peripherality issue discussion (Review stage A, 25 articles). No publication was found concerning both Rural Development and Cohesion Policy in the same search string (review stage E).

Figure 2. Number of publications by review step (1 and 2) and stage (A to E)

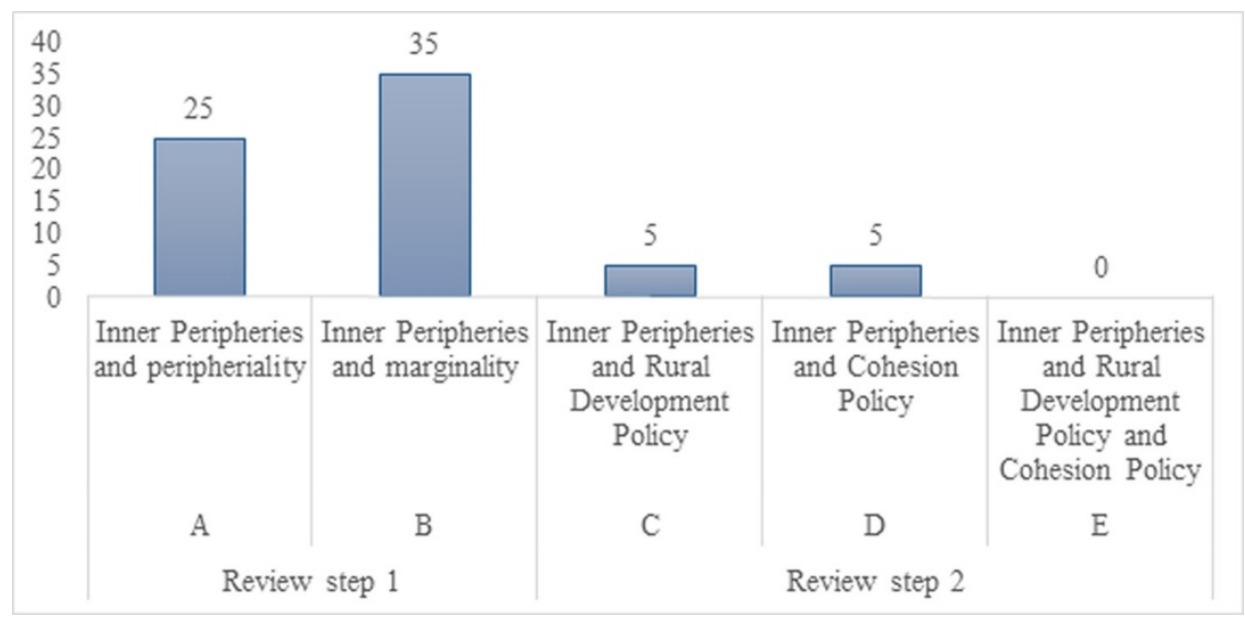

Source: authors' elaboration.

The results concerning the peripherality concept (review step 1, review stage A) show that the geographical location and accessibility (9 publications) and the lack of innovation (6 publications) are the most debated topics (see Figure 3a). According to the results related to the marginality concept (review step 1, review stage $B$ ), the mixed concepts of marginality is the most debated issue (13 publications), followed by the economic and ecologic marginality category (7 publications per each). On the other hand, the geometric (5 publications), social and political marginalities (1 publication and 2 publications, respectively) are not very much debated (see Figure $3 b$ ). 
Figure $3(\mathbf{a}, \mathbf{b})$. Spider charts reporting the number of cases for which a correlation between publication's contents and peripherality and marginality characteristics (a and b, respectively) is found
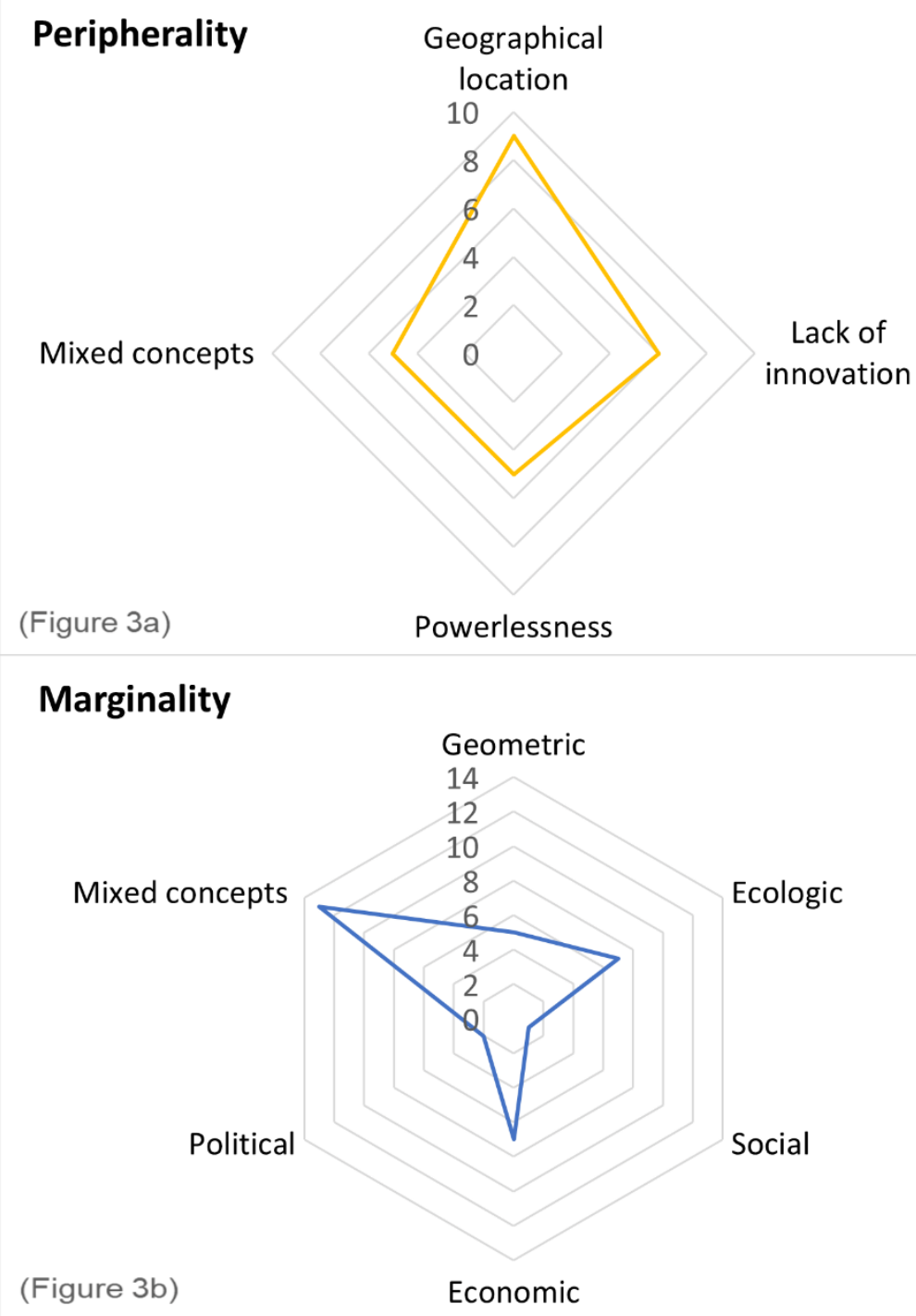

Source: authors’ elaboration.

The results concerning the Rural Development Policy (review step 2, review stage C) show that the 6th Policy Priority (i.e. "Social Inclusion and Economic Development") is treated in all the publications found (see Figure 4a). The 1st, 2nd and 3rd Priorities (i.e. "Knowledge Transfer and Innovation", "Farm Viability and Competitiveness" and "Food Chain Organization and Risk Management") are less debated. No publication treating the 4th and 5th Priorities (i.e., "Restoring, Preserving and Enhancing Ecosystems" and "Resource-efficient, Climate-resilient Economy”).

The results concerning the Cohesion Policy (review step 2, review stage D) show that the 11th Thematic Objective named "Improving the efficiency of public administration" is the most treated, followed by the 1st Objective, i.e., "Strengthening research, technological development and innovation" (see Figure 4b). Additional four Objectives are treated with the same frequency, as follows: the 3rd Objective ("Enhancing the competitiveness of small and medium-sized enterprises (SMEs)"), the 4th Objective (i.e., "Supporting the shift towards a low-carbon economy in all sectors"), the 5th Objective (i.e., "Promoting climate change adaptation, risk prevention and management"), the 6th 
Objective ("Preserving and protecting the environment and promoting resource efficiency"), and the 7th Objective (i.e., "Promoting sustainable transport and improving network infrastructures"). No publication was found as specifically regarding the 2nd Objective ("Enhancing access to, and use and quality of, information and communication technologies"), the 8th Objective ("Promoting sustainable and quality employment and supporting labour mobility"), the 9th Objective ("Promoting social inclusion, combating poverty and any discrimination"), and the 10th Objective ("Investing in education, training and lifelong learning”).

Figure 4 (a, b). Bar chart reporting the number of cases for which a correlation between publications' contents and Rural Development Policy Priorities (a), and Cohesion Policy Thematic Objectives (b) is found (review step 2, review stage $C$ and $D$ )

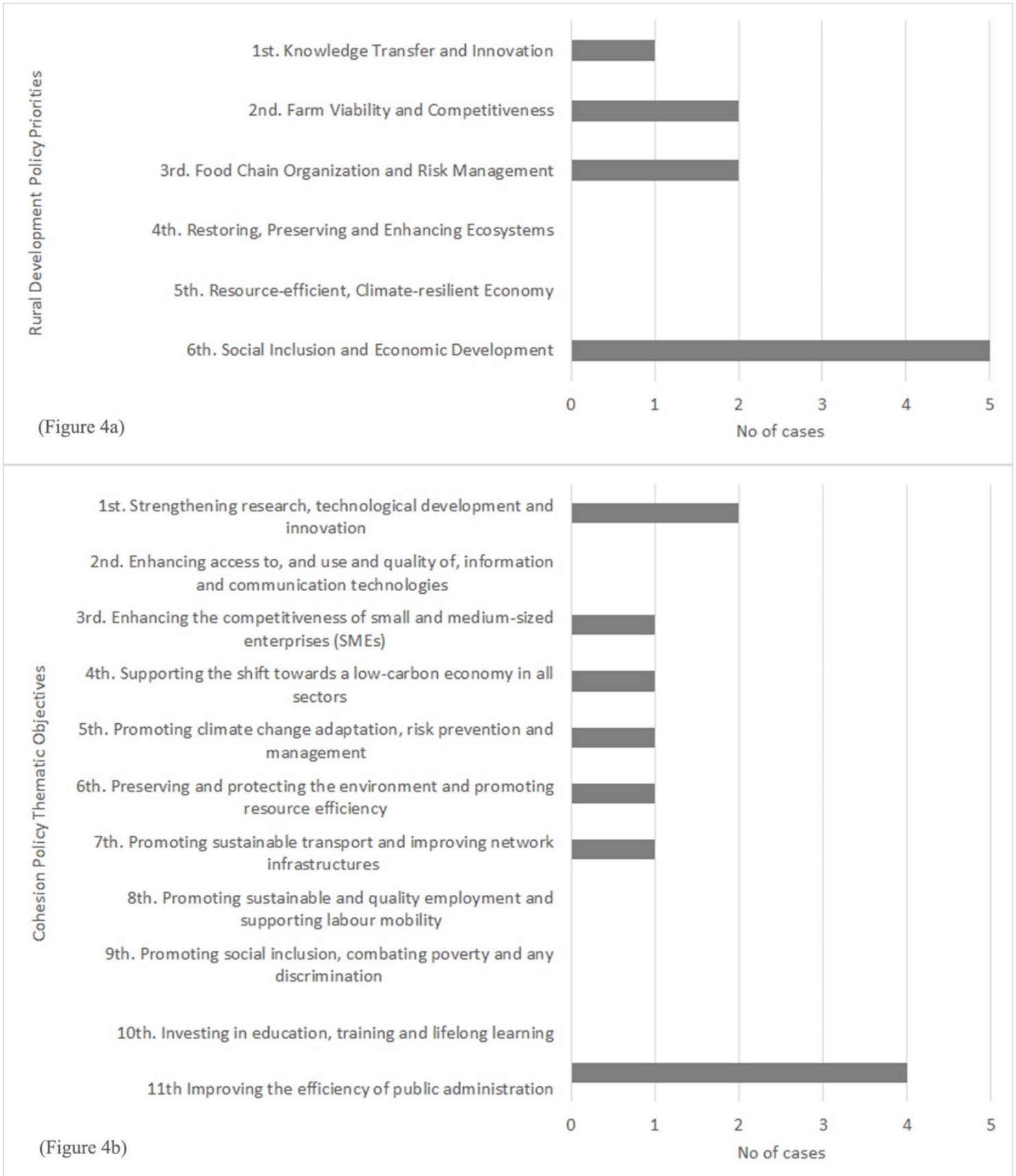

Source: authors’ elaboration. 


\section{DISCUSSION AND CONCLUSIONS}

The main findings highlight that more attention is given to the concept of marginality and peripherality (a total of 60 publications) than to the connection between Inner Peripheries and EU policies (a total of 10 publications). The results also highlight that there is no publication discussing both Policies in relation to the Inner Peripheries concept. Of course, these results depend on the set of keywords and their combination as adopted (see Table 1).

We hereinafter provide an overview of the major peripherality and marginality criticalities of the Inner Peripheries. Moreover, based on the main findings from the review exercise, we propose some territorial strategies and interventions that can be implemented in Inner Peripheries in order to address their major challenges through an integrated policy approach.

\subsection{Current criticalities for inner peripheries related to peripherality and marginality}

The review exercise aims to provide an overview of how Inner Peripheries are currently permeated by the marginality and peripherality issues, without focusing on the historical processes that generated peripherality and marginality conditions. In this respect, we found few publications discussing the Inner Peripheries combined with marginality or peripherality concepts (60 publications from 1966, see Figure 2). Concerning the peripherality concept, in most cases (9 publications) the Inner Peripheries are mainly identified by considering their geographical location, i.e. the remoteness and lack of accessibility to centres and SGIs. Instead, the marginality concept, as more complex, is debated in the largest part of publications by mixing geometric, socio-economic and political aspects. In general, the peripherality and marginality conditions are two different concepts in literature, as well as two intrinsically linked features in the reality, especially considering that "in most of Inner Peripheries the primary processes of peripheralization are associated with a range of secondary marginalisation processes" (ESPON, 2017). Thus, hereinafter we highlight how the peripherality conditions (e.g. remoteness) may lead to marginality features (e.g. low economic potential), based the literature results.

In detail, the Inner Peripheries are mainly characterized by peripheral location, outmigration (Anđelković-Stoilković, Devedžić, \& Vojković, 2018; Vaishar \& Pavlu, 2018), low accessibility and underdeveloped infrastructures (Lapka, Cudlínová, Rikoon, \& Bohác, 2001), which in turn create low economic potential (Koloszko-Chomentowska \& Sieczko, 2018) and socio-economic marginality. On the one hand, the distance from markets and limited accessibility to urban centres influence the related high costs for transportation (Mackenzie \& McEldowney, 1990), which in turn trigger problems for self-sustaining enterprises due to a lack of suppliers of materials and components in these remote areas (Gripaios, Bishop, Gripaios \& Herbert, 1989). On the other hand, the Inner Peripheries suffer from a lack of innovation compared to large core areas (Fitjar \& Rodríguez-Pose, 2011). This may be due not only to the remoteness, but also to the absence of widespread broadband infrastructures. Indeed, the rural-urban digital divide phenomenon currently represents one of the most important constraints for the economic development in Inner Peripheries (Rosina \& Hurbánek, 2013), because of their peripheral location. The geographical location is also correlated with environmental constraints, such as high altitude, steep conditions, short growing seasons and low soil fertility, which 
cause a lower economic productivity, especially for the agricultural sector (Bertaglia, Joost, \& Roosen, 2007). However, remote and economically marginal areas host vast networks of protected areas, especially in Southern Europe (i.e. ecologic marginality) (Cortes-Vazquez, 2017). At local scale, this may create an imbalance between economic exploitation and effective protection of natural resources.

The remoteness of these territories and the lack of SGIs influence the effectiveness of rural policies and public actions in general (i.e. political marginality): “communities with a good level of public services have a high level of awareness of the role of collective action and of the significance of public services as public goods" (Cecchi \& Basile 2006, p. 145). Thus, the lack (and in certain cases, poor effectiveness) of networks is perceived as a problem within the social and economic systems. The majority of the issues described so far have led to the land abandonment in Inner Peripheries, at least in Italy (Forleo, Giaccio, Giannelli, Mastronardi, \& Palmieri, 2017).

\subsection{Correlation between inner peripheries and cohesion and rural development policies}

Based on the review's outcomes, we found a relatively weak connection between Inner Peripheries concept and the Cohesion and Rural Development Policies. Indeed, there is still limited literature treating the Inner Peripheries in relation to the Cohesion and Rural Development Policies, separately (a total of 10 publications; Figure 2), and no publication focusing on Inner Peripheries with regards to both Policies.

The results highlight that the Rural Development Priorities are mainly correlated to the enhancement of the economic and social sectors. On the contrary, the Priorities specifically concerning the environmental issues are neglected (see Figure 4a). Even concerning the Cohesion Thematic Objectives, the environmental issues are discussed only in one publication (see Figure 4b). These results were partly expected, especially taking into account that the two main sources of information about Inner Peripheries (i.e. ESPON 2017 and Italian National Strategy for Inner Areas) do not consider the environmental characteristics of these territories (e.g. presence of biodiversity hotspots, areas covered by agricultural and forestry land, hydrological risk issue). In detail, the 4th and 5th Priorities of the Rural Development Policy and the 6th Thematic Objective of the Cohesion Policy generally focus on the enhancement of biodiversity, the soil erosion prevention and water management improvement especially in agriculture, and the renewable sources of energy use. Since Inner Peripheries cover $80 \%$ of rural areas in Europe (ESPON, 2018) and their productive capacity is mainly based on agriculture and forestry sectors (Matthews, 2016), the exploration of the environmental aspects is currently lacking.

On the contrary, the 6th Rural Development Policy Priority, i.e. "Social Inclusion and Economic Development", is treated in all publications related to Inner Peripheries and Rural Development Policy. Even in this case, the result was rather expected, since the major criticalities in the Inner Peripheries as described in literature, i.e. depopulation trend, population ageing and young outmigration, lack of SGIs and low economic potential, may be reduced by using the 6th Priority funds. Moreover, we did not find literature resources specifically addressing the linkages between the two main EU Policies, in particular with regards to the 6th Rural Development Priority "Social Inclusion and Economic Development" and the potentially related Thematic Objectives of the Cohesion Policy. In detail, the efforts to foster the rural development in Inner Peripheries may be supported by different Thematic Objectives such as "enhance access 
to, and use and quality of, ICT" (2nd Thematic Objective), "promote sustainable and quality employment and supporting labour mobility” (8th Thematic Objective), "promote social inclusion, combating poverty and any discrimination" (9th Thematic Objective) and "invest in education, training and vocational training for skills and lifelong learning by developing education and training infrastructure" (10th Thematic Objective).

Instead, the 11th Thematic Objective "improve the efficiency of public administration" is treated in many publications, mainly referring to the participation in decision-making processes, as well as to the Italian National Strategy for Inner Areas (Francini, Palermo \& Viapiana, 2017; Las Casas, Murgante \& Scorza, 2016). This could be linked to the sensitive topic of the "place-based approach" (Barca 2009), on which the Italian National Strategy for Inner Areas is based.

\subsection{Reducing inner peripheries criticalities}

It may be possible to reduce the Inner Peripheries' criticalities through focusing on the potentialities of a peripheral location while inverting the marginalisation processes through the efficient use of the Rural Development and Cohesion Policies funds. Indeed, there is the need to implement an integrated policy approach, such as the "Rural Cohesion Policy” framework (Dax \& Copus, 2018), to concurrently foster the rural development and the territorial cohesion dimensions in Inner Peripheries.

In detail, the opportunities to sustainably develop the Inner Peripheries should be mainly correlated with valuing both natural and human capital, while paying closer attention to the combination of the economic and social aspects. The environmental relevance of the Inner Peripheries should be valorised through re-establishing traditional uses (Burton \& Riley 2018), enhancing the ecosystem services originated by natural capital (e.g. Marino \& Pellegrino 2018), or even promoting the natural and cultural heritages in such contexts. These interventions could be financed by the 4th Rural Development Priority and the 6th Cohesion Policy Thematic Objective.

In addition, the tourism sector is one of the most feasible options to develop and regenerate these territories (Těšitel, Kušová, \& Bartoš, 1999), through e.g. the stewardship of rural heritage and environmental conservation (or care) (Boniface, 2000). Tourism can be combined with the re-emergence and development of traditional vocations and enterprises, thus encouraging the endogenous growth (Garrod \& Wilson, 2004) and fostering the community-based tourism (Salvatore, Chiodo, \& Fantini, 2018).

Moreover, it is essential to prioritize the access to the broadband connection, in order to stimulate innovation in the local economy and improve social wellbeing in these remote areas (through e.g. the 1st and 2nd Cohesion Thematic Objectives and 6th Rural Development Priority funds). Indeed, nowadays the information and communication technology are essential to improve the smallholders' competitiveness (Townsend, Wallace, \& Fairhurst, 2015), and services such as the telemedicine (Whitacre, Wheeler, \& Landgraf, 2017), and finally guarantee a prompt and continuous health care interventions (Balestrieri et al., 2019; Kvernflaten, 2019).

Moreover, to further encourage the sustainable socio-economic development in Inner Peripheries, feasible pathways may consider for example, the implementation of concepts such as multifunctional agriculture and forestry (Sutherland \& Huttunen, 2018), circular and bio-based economies (Marchetti et al. 2014), and the promotion of climate change adaptation and mitigation strategies. These interventions may be coupled with innovative productions and markets (e.g. Sallustio et al. 2018), as well as with landscape labelling 
approaches (Mann \& Plieninger, 2017). Such interventions can promote local goods (e.g., local foods) and rural landscape amenities, and create jobs. This is for example the case of fostering the small and medium size enterprises and agricultural holdings (Che, 2007) which could guarantee sustainable employment in these areas, and discourage younger generations to move. These interventions may be supported by the 1st, 2nd, 3rd, 5th and 6th Rural Development Priorities and the 3rd, 4th, 5th, 8th and 10th Cohesion Policy Thematic Objectives. Moreover, the landscape amenities and the environmental aspects are the key factors to reactivate the social framework (i.e. the environment as driving force for the re-emergence of local identity) via the lens of the so-called "relational values" (Chan et al., 2016), and strengthen the sustainable economic development in these territories (i.e. active natural resources management).

Thus, it is important to stimulate the most representative economic sectors (i.e. agriculture and forestry) and community-based solutions, and simultaneously foster the social cohesion and inclusion, following the 9th Cohesion Policy Thematic Objective. The establishment and maintenance of effective enterprises' networks, cooperatives, and groups of smallholders may increase the economic revenues from less productive areas and diversify the production chain (Tregear \& Cooper, 2016). In this perspective, it is extremely important to combine the development of new products with the establishment of stronger connections between centres and Inner Peripheries (Pezzi \& Urso, 2017) through e.g., the rail and train network development (through the 7th Cohesion Policy Thematic Objective fund use).

More comprehensively, policies and community-based solutions are expected to enhance latent resources and encourage innovation processes. The Inner Peripheries suffer from the "underestimation of local capital by stakeholders and lack of wider strategic thinking" (Hall, Birtwistle, \& Gladstone, 2011), and the scarce representation of social and institutional actors. It is thus extremely important to foster the development of the local capital by considering the local needs (Dax \& Fischer, 2018), and to re-establish the socio-political connectivity (Bock, 2016). A possible strategy would be strengthening the communication between different administration levels and local communities (De Filippi et al., 2016; Wójcik, Dmochowska-Dudek, Jeziorska-Biel, \& Tobiasz-Lis, 2018), and enhancing the involvement of inhabitants and stakeholders in decision-making processes (Salvatore, Chiodo, \& Fantini, 2018) in agreement with the 11th Cohesion Policy Thematic Objective. Accordingly, it is also essential to increase the financial and organizational capacity in these areas for accessing to European funds (Cañete, Navarro \& Cejudo 2018), and ultimately fostering the local empowerment (Labianca \& Navarro, 2019).

A further improvement of the research activities in deeper understanding the consistency between the Inner Peripheries, and the Cohesion and Rural Development Policies would provide more robust and accurate evidences to support local planning and policy-making processes. In this way, the promotion in EU of the Integrated Territorial Investments (ITI) tool (European Commission, 2015) would enable a more comprehensive approach in the use of EU funds and more coordinated investments in the Inner Peripheries' territories.

Moreover, the implementation of the EU Cohesion and Rural Development Policies should be made more effective through commonly defining the main characteristics of Inner Peripheries, harmonizing currently available information systems, and implementing robust scientific multi-disciplinary methods and approaches based for example, on comprehensive indicators framework based on land use-land cover characteristics (e.g. LUISA Territorial Modelling Platform; Jacobs-Crisioni et al., 2016; Lotze-Campen et al., 2018). The EU policies should convey to a common target, and put 
the concept of "territory" at the basis of EU regions-oriented policies, better addressing the context specificities (Leco \& Pérez, 2019), and in order to limit the overlaps among funding sources and emphasize the possible synergies. Some authors tried to ex-post assess the economic and social impacts of projects supported by EU funds (2007-2013 programming period) at the municipal and national scales (Kouřilová \& Pělucha, 2017). However, a contextualized ex-ante analysis incorporating specific territorial needs and priorities would be promising and useful (Las Casas et al., 2016), particularly to consider specific regional diversities (ESPON 2013b) with a place-based approach (Barca, 2009; Copus et al., 2017).

\section{FINAL REMARKS}

The present work is a first attempt to convey the currently available scientific knowledge on the Inner Peripheries. Through the review exercise, we described the main issues and challenges for Inner Peripheries as expressed in the scientific debate. We also explored the theoretical connections between Inner Peripheries and Cohesion and Rural Development Policies, as discussed in the research and science domains. Nevertheless, despite the robustness and replicability of our approach, the results are strictly related to the combination of keywords used and conceived to detect publications strictly related to “Cohesion Policy” and "Rural Development Policy”. Moreover, our review excludes additional information sources from social and economic contexts (such literature produced by local or national organisations) which could be potentially relevant to complement the current knowledge on Inner Peripheries. We deem that grey literature is certainly important to complement the understanding of local to national processes and dynamics. However, the review exercise focused on a broader scale than the national one. As a consequence, it is difficult to disclose any possible translation of the broad conceptualization of the Inner Peripheries into individual national contexts. Despite these limitations, the present work offers a comprehensive starting point for potential discussion on external social and economic forces acting at national and regional scale to effectively orient funding opportunities towards the sustainable development of these territories.

Based on main findings, the Inner Peripheries need to improve their competitiveness through fostering productive capacity, establishing a sustainable use of local resources, and making more efforts to bridge the innovation and technology gaps than centres. This can be achieved through e.g. adopting labelling and marketing tools for the supply and trade of local products, incentivizing the establishing of cooperatives or small-scale farming groups, and investing in sustainable agriculture and forestry use (shortened source-product chain). Also, it is necessary to strengthen the inclusive participation of the local communities in decision-making processes, and maintain places and traditions, by including the improvement of the related productive and cultural attractiveness. Of course, it is difficult to achieve all these interventions simultaneously, due to the implications of balancing immediate local needs, policy and planning rules, and funding opportunities. Based on our results, we can argue that priority should be given to further explore the possibility to combine rural development and territorial cohesion, through for example, incentivizing land management activities (agro-forestry sector) in abandoned areas, and thus re-coupling the human and natural systems. Focusing policies efforts on these aspects may be the chance for the renaissance of the Inner Peripheries. 


\section{REFERENCES}

Anđelković-Stoilković, M., Devedžić, M., \& Vojković, G. (2018). The border regions of Serbia: Peripheral or marginal areas. Trames, 22 (2), 211-227. https://doi.org/10.3176/tr.2018.2.07.

Balestrieri, E., Boldi, F., Colavita, A. R., De Vito, L., Laudato, G., Oliveto, R., ... Tudosa, I. (2019). The architecture of an innovative smart T-shirt based on the Internet of Medical Things paradigm. International Symposium on Medical Measurements and Applications (MeMeA). Retrieved from: https://ieeexplore.ieee.org/document/8802143 (21/04/2020).

Barca, F. (2009). Agenda for a Reformed Cohesion Policy. European Communities. Retrieved from: https://www.europarl.europa.eu/meetdocs/2009_2014/documents/regi/dv/barca_re port_/barca_report_en.pdf (19/04/2020).

Barca, F. (2012). Metodi e obiettivi per un uso efficace dei Fondi comunitari 2014-2020. Retrieved from: https://www.miur.gov.it/documents/20182/890263/metodi_e_obiettivi_per_uso_e fficace_dei_fondi_comunitari_14_20.pdf/456c31f2-8e71-4b4c-aa380023e3958872 (19/04/2020).

Barca, F., Casavola, P., \& Lucatelli, S. (2014). A Strategy for Inner Areas in Italy: definition, objectives, tools and governance. Materiali UVAL Series, (31). 66 pp. Retrieved from: http://old2018.agenziacoesione.gov.it/opencms/export/sites/dps/it/documentazion e/servizi/materiali_uval/Documenti/MUVAL_31_Aree_interne_ENG.pdf $(19 / 04 / 2020)$.

Bertaglia, M., Joost, S., \& Roosen, J. (2007). Identifying European marginal areas in the context of local sheep and goat breeds conservation: A geographic information system approach. Agricultural Systems, 94 (3), 657-670. https://doi.org/10.1016/j.agsy.2007.02.006

Bock, B. (2016). Rural marginalisation and the role of social innovation; a turn towards nexogenous development and rural reconnection. Sociologia Ruralis, 56 (4), 552573. https://doi.org/10.1111/soru.12119

Böhme, K. (2016). Territorial evidence supporting policy-making in Europe: How ESPON came, saw and conquered. disP-The Planning Review, 52 (2), 62-67. Retrieved from: https://www.tandfonline.com/doi/abs/10.1080/02513625.2016.1195589 $(21 / 04 / 2020)$.

Boniface, P. (2000). Behind the scenes: Tourism, and heritage, in the periphery to the French Mediterranean coast. International Journal of Heritage Studies, 6 (2), 129144. https://doi.org/10.1080/135272500404188

Brezzi, M., Dijkstra, L., \& Ruiz, V. (2011). OECD Extended Regional Typology: The Economic Performance of Remote Rural Regions. Retrieved from: http://www.oecd.org/cfe/regional-policy/48670214.pdf (19/04/2020). 
Burton, R. J. F., \& Riley, M. (2018). Traditional Ecological Knowledge from the internet? The case of hay meadows in Europe. Land Use Policy, (70), 334-346. https://doi.org/10.1016/j.landusepol.2017.10.014

Cañete, J., Navarro, F. and Cejudo, E. (2018). Territorially unequal rural development: the cases of the LEADER Initiative and the PRODER Programme in Andalusia (Spain). European Planning Studies, $27 \quad$ (2), 396-414. https://doi.org/10.1080/09654313.2018.1424118

Carrosio, G. (2016). A place-based perspective for welfare recalibration in the Italian inner peripheries: the case of the Italian Strategy for Inner Areas. Sociologia e Politiche Sociali, 19 (3), 50-64. https://doi.org/10.3280/SP2016-003004

Cecchi, C., \& Basile, E. (2006). Public action and social capital in rural areas. WIT Transactions on Ecology and the Environment, (99), 137-146. https://doi.org/10.2495/RAV060141

Cesaro, L., \& Marongiu, S. (2017). Economic performance and profitability of agricultural holdings in Inner Areas. Italian Journal of Planning Practice, 7 (1), 100-124. Retrieved from: http://www.ijpp.it/index.php/it/article/view/75 $(19 / 04 / 2020)$.

Chan, K. M. A., Balvanera, P., Benessaiah, K., Chapman, M., Díaz, S., GómezBaggethun, E., ... Turner, N. (2016). Opinion: Why protect nature? Rethinking values and the environment. Proceedings of the National Academy of Sciences, 113 (6), 1462-1465. https://doi.org/10.1073/pnas.1525002113

Che, D. (2007). Agritourism and its potential contribution to the agricultural economy. CAB Reviews: Perspectives in Agriculture, Veterinary Science, Nutrition and Natural Resources, (2). https://doi.org/10.1079/PAVSNNR20072063

Copus, A., Mantino, F., \& Noguera, J. (2017). Inner peripheries: An oxymoron or a real challenge for territorial cohesion? Italian Journal of Planning Practice, VII (1), 2449. Retrieved from: http://www.ijpp.it/index.php/it/article/view/77 (15/04/2020).

Cortes-Vazquez, J. A. (2017). The end of the idyll? Post-crisis conservation and amenity migration in natural protected areas. Journal of Rural Studies, (51), 115-124. https://doi.org/10.1016/j.jrurstud.2017.02.005

Dax, T., \& Copus, A. (2018). Towards vibrant, inclusive and sustainable rural regions: orientations for a future Rural Cohesion Policy. European Structural and Investments Funds Journal, 6 (3), 198-209. Retrieved from: https://estif.lexxion.eu/article/ESTIF/2018/3/3 (13/04/2020).

Dax, T., \& Fischer, M. (2018). An alternative policy approach to rural development in regions facing population decline. European Planning Studies, (26), 297-315. https://doi.org/10.1080/09654313.2017.1361596 (13/04/2020).

De Filippi, F., Coscia, C., Boella, G., Antonini, A., Calafiore, A., Cantini, A., ... Schifanella, C. (2016). MiraMap: A We-Government Tool for Smart Peripheries in Smart Cities. IEEE Access, (4), 3824-3843. https://doi.org/10.1109/ACCESS.2016.2548558

Duquenne, M.-N., \& Hadjou, L. (2011). A theoretical and methodological approach of "Fragile" Areas: the cases of Greek Regions crossed by the Egnetia road. Regional Science Inquiry, 0 (2), 45-58. Retrieved from: 
https://econpapers.repec.org/article/hrsjournl/v_3av_3ay_3a2013_3ai_3a2_3ap_3 a45-58.htm (19/04/2020).

ESPON (2013a). Inner Peripheries: a socio-economic territorial specifity. GEOSPECS (ESPON Project). Retrieved from: https://www.espon.eu/programme/projects/espon-2013/appliedresearch/geospecs-geographic-specificities-and-development (19/04/2020).

ESPON (2013b). Final Report. EDORA - European development opportunities for rural areas. Retrieved from: https://www.espon.eu/programme/projects/espon2013/applied-research/edora-european-development-opportunities-rural-areas (19/04/2020).

ESPON (2017). Final Report. PROFECY - Processes, Features and Cycles of Inner Peripheries in Europe. Inner Peripheries: National territories facing challenges of access to basic services of general interest. Luxembourg. Retrieved from: https://www.espon.eu/inner-peripheries (19/04/2020).

ESPON (2018). Inner Peripheries in Europe. Possible development strategies to overcome their marginalising effects. Retrieved from: https://www.espon.eu/sites/default/files/attachments/ESPON-Policy-Brief-InnerPeripheries.pdf (19/04/2020).

European Commission. (2015). Scenarios for Integrated Territorial Investments. Retrieved from: https://ec.europa.eu/regional_policy/es/information/publications/reports/2015/scen arios-for-integrated-territorial-investments (19/04/2020).

Fitjar, R.D., \& Rodríguez-Pose, A. (2011). Innovating in the periphery: Firms, values and innovation in Southwest Norway. European Planning Studies, 19 (4), 555-574. https://doi.org/10.1080/09654313.2011.548467

Forleo, M. B., Giaccio, V., Giannelli, A., Mastronardi, L., \& Palmieri, N. (2017). Socioeconomic drivers, land cover changes and the dynamics of rural settlements: Mt. Matese area (Italy). European Countryside, 9 (3), 435-457. https://doi.org/10.1515/euco-2017-0026

Francini, M., Palermo, A., \& Viapiana, M. F. (2017). Inland areas: An important territorial "slant" for the definition of integrated regional cohesion policies [Aree interne: Un'importante "inclinazione" territoriale per integrate politiche di coesione]. Territorio, (80), 132-139. https://doi.org/10.3280/TR2017-080018

Friedmann, J. (1966). Regional development policy: a case study of Venezuela. Massachusetts. M.I.T. Press. Retrieved from: https://mitpress.mit.edu/books/regional-development-policy (19/04/2020).

Garrod, B., \& Wilson, J. C. (2004). Nature on the edge? marine ecotourism in peripheral coastal areas. Journal of Sustainable Tourism, 12 (2), 95-120. https://doi.org/10.1080/09669580408667227

Gripaios, P., Bishop, P., Gripaios, R., \& Herbert, C. (1989). High Technology Industry in a Peripheral Area: The Case of Plymouth. Regional Studies, 23 (2), 151-157. https://doi.org/10.1080/00343408912331345372

Hall, D., Birtwistle, M., \& Gladstone, J. (2011). Semi-rural marginal areas, 'Inbetweenness' and tourism integration in South-West Scotland. Tourism Recreation Research, $36 \quad$ (1), 3-14. Retrieved from: 
https://www.tandfonline.com/doi/abs/10.1080/02508281.2011.11081655?journal Code=rtrr20 (19/04/2020).

Jacobs-Crisioni, C., Batista e Silva, F., Lavalle, C., Baranzelli, C., Barbosa, A., \& Perpiña Castillo, C. (2016). Accessibility and territorial cohesion in a case of transport infrastructure improvements with changing population distributions. European Transport Research Review, 8 (1), 1-16. https://doi.org/10.1007/s12544-016-01975

Kebza, M. (2018). The development of peripheral areas: The case of West Pomeranian Voivodeship, Poland. Moravian Geographical Reports, 26 (1), 69-81. https://doi.org/10.2478/mgr-2018-0006

Koloszko-Chomentowska, Z., \& Sieczko, L. (2018). Peripheral rural areas in face of challenges of sustainable development. Engineering for Rural Development, (17), 1160-1165. https://doi.org/10.22616/ERDev2018.17.N277

Kouřilová, J., \& Pělucha, M. (2017). Economic and Social Impacts of Promoting Cultural Heritage Protection by the Czech Rural Development Programme 2007-2013. European Countryside, 9 (3), 486-503. https://doi.org/10.1515/euco-2017-0029

Kühn, M. (2015). Peripheralization: Theoretical Concepts Explaining Socio-Spatial Inequalities. European Planning Studies, 23 (2), 367-378. https://doi.org/10.1080/09654313.2013.862518

Kvernflaten, B. (2019). Reinforcing marginality? Maternal health interventions in rural Nicaragua. Anthropology and Medicine, 26 (1), 87-103. https://doi.org/10.1080/13648470.2017.1333570

Labianca, M., \& Navarro, F. (2019). Depopulation and aging in rural areas in the European Union: practices starting from the LEADER approach. In E. Cejudo and F. Navarro (eds.), Despoblación y transformaciones sociodemográficas de los territorios rurales: los casos de España, Italia y Francia. Perspectives on rural development, 3 (pp. 223-252), University of Salento. https://doi.org/10.1285/i26113775n3p223

Lapka, M., Cudlínová, E., Rikoon, S., \& Bohác, J. (2001). Use of linear and non-linear approaches to solving the problems of marginal areas. International Journal of Sustainable Development, 4 (2), 157-176. Retrieved from: https://ideas.repec.org/a/ids/ijsusd/v4y2001i2p157-176.html (19/04/2020).

Las Casas, G., Murgante, B., \& Scorza, F. (2016). Regional local development strategies benefiting from open data and open tools and an outlook on the renewable energy sources contribution. Green Energy and Technology, 275-290. https://doi.org/10.1007/978-3-319-31157-9_14

Leco, F., \& Pérez, A. (2019). Desajustes territoriales en la distribución del Pago Básico de la PAC en España. Cuadernos Geográficos, 58 (3), 57-82. http://dx.doi.org/10.30827/cuadgeo.v58i3.8633

Lotze-Campen, H., Verburg, P.H., Popp, A., Lindner, M., Verkerk, P.J., Moiseyev, A., ... Bodirsky, B. (2018). A cross-scale impact assessment of European nature protection policies under contrasting future socio-economic pathways. Regional Environmental Change, 18 (3), 751-762. https://doi.org/10.1007/s10113-0171167-8 
Lucatelli, S., Carlucci, C., \& Guerrizio, M. A. (2013). A Strategy for the "Inner Areas" of Italy. In M. Gather, A. Lüttmerding, J. Berding, \& G. Pablos Villarroel (eds.), Proceedings of the 2nd EURUFU (Education, Local Economy and Job Opportunities in Rural Areas) Scientific Conference. Asti (Italy), 8 October. Retrieved from: https://www.dbthueringen.de/servlets/MCRFileNodeServlet/dbt_derivate_00029059/Verkehr\%20 und\%20Raum\%2016.pdf (19/04/2020).

Mackenzie, R. H., \& McEldowney, J. J. (1990). Reducing the effects of peripherality within the European Community. Planner, 76 (30), 9-13. ISSN: 0309-1384 Retrieved from https://trid.trb.org/view/366516

Máliková, L., \& Klobučník, M. (2017). Differences in the rural structure of Slovakia in the context of socio-spatial polarisation. Quaestiones Geographicae, 36 (2), 125140. https://doi.org/10.1515/quageo-2017-0020

Mann, C., \& Plieninger, T. (2017). The potential of landscape labelling approaches for integrated landscape management in Europe. Landscape Research, 42 (8), 904-920. https://doi.org/10.1080/01426397.2017.1335863

Mantino, F., \& De Fano, G. (2015). New concepts for territorial rural development in Europe: the case of Inner Areas in Italy. In K. Brown, M. Currie, R. do Carmo, J. Duncan, M. Kohe, A. Koutsouris, ... M. Woods (eds.), European Society for Rural Sociology Congress. Proceedings of Proceedings of the XXVI Congress. Places of Possibility? Rural Societies in a Neoliberal World, (pp. 101-102). Scotland. Retrieved from: https://rural.hypotheses.org/files/2016/03/FINAL-ESRSCongress-Proceedings.pdf (19/04/2020).

Marchetti, M., De Toni, A., Sallustio, L., \& Tognetti, R. (2017). Criticità e opportunità di sviluppo per le aree interne. In M. Marchetti, A. De Toni, L. Sallustio, \& R. Tognetti (eds.), Aree interne. Per una rinascita dei territori rurali e montani (pp. 27-37), Rubbettino Editore.

Marchetti, M., Vizzarri, M., Lasserre, B., Sallustio, L., \& Tavone, A. (2014). Natural capital and bioeconomy: Challenges and opportunities for forestry. Annals of Silvicultural Research, 38 (2), 62-73. https://doi.org/10.12899/ASR-1013

Marino, D., \& Pellegrino, D. (2018). Can payments for ecosystem services improve the management of natura 2000 sites? A contribution to explore their role in Italy. Sustainability, 10 (3), 665. https://doi.org/10.3390/su10030665

Matthews, A. (2016). Research for AGRI Committee, CAP Reform Post-2020, Challenges in Agriculture. Brussels: European Union. Retrieved from: https://www.europarl.europa.eu/RegData/etudes/STUD/2016/585898/IPOL_STU( 2016)585898_EN.pdf (19/04/2020).

Ministry of National Development and VÁTI Nonprofit Ltd. (2011). The Territorial State and Perspectives of the European Union. Background document of the Territorial Agenda of the European Union 2020. Retrieved from: https://ec.europa.eu/regional_policy/sources/policy/what/territorialcohesion/territorial_state_and_perspective_2011.pdf (19/04/2020).

Nagy, E., Timár, J., Nagy, G., \& Velkey, G. (2015). The Everyday Practices of the Reproduction of Peripherality and Marginality in Hungary. In T. Lang, S. Henn, W. Sgibnev, \& K. Ehrlich (eds.), Understanding Geographies of Polarization and 
Peripheralization: Perspectives from Central and Eastern Europe and Beyond, (pp. 135-155). Palgrave Macmillan UK. https://doi.org/10.1057/9781137415080_8

Noguera, J., \& Copus, A. (2016). Inner Peripheries: What are they? What policies do they need? Agriregionieuropa, (45). Retrieved from: https://agriregionieuropa.univpm.it/it/content/article/31/45/inner-peripherieswhat-are-they-what-policies-do-they-need (19/04/2020).

Osti, G. (2016). The Unbalanced Welfare of Italian Fragile Rural Areas. In U. GrabskiKieron, I. Mose, A. Reichert-Schick, \& Steinfurher (eds.), A European Rural Peripheries Revalued, Governance, Actors, Impacts (pp. 64-88), Ed. Lit Verlag.

Pagano, G., \& Losco, S. (2016). EU Cohesion-Policies and Metropolitan Areas. In F. Calabrò \& L. Della Spina (eds.), Procedia-Social and Behavioral Sciences, 2nd Intern, Vol. 223 (pp. 422-428). Ed. Reggio Calabria, Italy.

Pezzi, M. G., \& Urso, G. (2017). Coping with peripherality: Local resilience between policies and practices. Editorial note. Italian Journal of Planning Practice, 7 (1), 123. Retrieved from: http://www.ijpp.it/index.php/it/article/view/76 (19/04/2020).

Pileček, J., \& Jančák, V. (2011). Theoretical and methodological aspects of the identification and delimitation of peripheral areas. Acta Universitatis Carolinae, Geographica, 46 (1), 43-52. https://doi.org/10.14712/23361980.2015.41

Rosina, K., \& Hurbánek, P. (2013). Internet availability as an indicator of peripherality in Slovakia [Dostupnost internetu jako indikátor perifernosti na Slovensku]. Moravian Geographical Reports, 21 (1), 16-24. Retrieved from: https://content.sciendo.com/view/journals/mgr/21/1/article-p16.xml (19/04/2020).

Saccomani, S. (2014). Torino: a Metropolitan City of 315 Municipalities. Urbanistica, (153), 102-105. Retrieved from: https://issuu.com/planumnet/docs/urbanistica_153 (19/04/2020).

Sallustio, L., Pettenella, D., Merlini, P., Romano, R., Salvati, L., Marchetti, M., \& Corona, P. (2018). Assessing the economic marginality of agricultural lands in Italy to support land use planning. Land Use Policy, (76), 526-534. https://doi.org/10.1016/j.landusepol.2018.02.033

Salvatore, R., Chiodo, E., \& Fantini, A. (2018). Tourism transition in peripheral rural areas: Theories, issues and strategies. Annals of Tourism Research, (68), 41-51. https://doi.org/10.1016/j.annals.2017.11.003

Scrofani, L., \& Novembre, C. (2015). The inland areas of Sicily. From rural development to territorial reorganization. Semestrale Di Studi e Ricerche Di Geografia, 1. Retrieved from: https://annalidibotanica.uniroma1.it/index.php/semestralegeografia/article/view/15115 (19/04/2020).

Sutherland, L.-A., \& Huttunen, S. (2018). Linking practices of multifunctional forestry to policy objectives: Case studies in Finland and the UK. Forest Policy and Economics, (86), 35-44. https://doi.org/10.1016/j.forpol.2017.10.019

Těšitel, J., Kušová, D., \& Bartoš, M. (1999). Non-marginal parameters of marginal areas. Ekologia Bratislava, 18 (1), 39-46. Retrieved from: https://www.researchgate.net/publication/298962397_Nonmarginal_parameters_of_marginal_areas (19/04/2020). 
Townsend, L., Wallace, C., \& Fairhurst, G. (2015). 'Stuck Out Here’: The Critical Role of Broadband for Remote Rural Places. Scottish Geographical Journal, 131 (3-4), 171-180. https://doi.org/10.1080/14702541.2014.978807

Tregear, A., \& Cooper, S. (2016). Embeddedness, social capital and learning in rural areas: The case of producer cooperatives. Journal of Rural Studies, (44), 101-110. https://doi.org/10.1016/j.jrurstud.2016.01.011

Vaishar, A., \& Pavlu, A. (2018). Outmigration intentions of secondary school students from a rural micro-region in the Czech inner periphery: A case study of the Bystrice nad Pernštejnem area in the Vysočina Region. Acta Universitatis Carolinae, Geographica, 53 (1), 49-57. https://doi.org/10.14712/23361980.2018.5

Whitacre, B. E., Wheeler, D., \& Landgraf, C. (2017). What Can the National Broadband Map Tell Us About the Health Care Connectivity Gap? Journal of Rural Health, 33 (3), 284-289. https://doi.org/10.1111/jrh.12177

Wójcik, M., Dmochowska-Dudek, K., Jeziorska-Biel, P., \& Tobiasz-Lis, P. (2018). Understanding strategies for overcoming peripherality: A Polish experience of transition. Bulletin of Geography, 40 (40), 173-192. https://doi.org/10.2478/bog2018-0022. 


\section{Appendix 1. List of synonyms and similar terms, including their definition, as correlated with the Inner Peripheries concept. (1) Similar terms and synonyms are used as part of keywords in search strings (see Table 1)}

\begin{tabular}{|c|c|c|c|}
\hline $\begin{array}{l}\text { Similar terms } \\
\text { synonyms }\left({ }^{1}\right)\end{array}$ & $\begin{array}{l}\text { Linkage with } \\
\text { the Inner } \\
\text { Peripheries' } \\
\text { concept } \\
\end{array}$ & $\begin{array}{c}\text { Definition and connections with Cohesion Policy and Rural } \\
\text { Development Policy n }\end{array}$ & Source \\
\hline $\begin{array}{l}\text { Remote } \\
\text { Rural } \\
\text { Regions }\end{array}$ & Similar term & $\begin{array}{l}\text { The OECD Regional typology classification is based on the } \\
\text { "percentage of regional population living in urban or rural } \\
\text { communities". The extension of this classification includes the } \\
\text { accessibility criterion, the driving time (DT) needed to reach a } \\
\text { highly populated centre (DT "of at least 50\% of the regional } \\
\text { population to the closest populated centre with more than } \\
50.000 \text { Inhabitants"). For the Predominantly Rural Remote, the } \\
\text { DT is greater than } 45 \text { minutes (Italian Department for Cohesion } \\
\text { Policies and Lucatelli, Carlucci and Guerrizio 2013, Inner } \\
\text { Areas DT is greater than } 40 \text { minutes from SGIs - Peripheral } \\
\text { and Ultra-Peripheral Areas; ESPON PROFECY a mean of } 30 \\
\text { minutes from SGIs). }\end{array}$ & $\begin{array}{l}\text { (Brezzi, Dijkstra, } \\
\text { \& Ruiz 2011, pp. } \\
\text { 3, 6) }\end{array}$ \\
\hline $\begin{array}{l}\text { Peripheral } \\
\text { Areas }\end{array}$ & Similar term & $\begin{array}{l}\text { "Periphery, peripherality and peripheral area are, in general, } \\
\text { more frequently used terms", and concern marginality and } \\
\text { peripherality concepts explanations. }\end{array}$ & $\begin{array}{l}\text { (Pileček \& Jančák } \\
\text { 2011, p. 45) }\end{array}$ \\
\hline $\begin{array}{l}\text { Marginal } \\
\text { Areas }\end{array}$ & Similar term & $\begin{array}{l}\text { "Marginality is shaped more by a "multi-dimensional" } \\
\text { spectrum of problems, from economic and cultural to social, } \\
\text { political and historical ones". }\end{array}$ & $\begin{array}{l}\text { (Pileček \& Jančák } \\
\text { 2011, p. 45) }\end{array}$ \\
\hline $\begin{array}{l}\text { Internal } \\
\text { Peripheries }\end{array}$ & Similar term & $\begin{array}{l}\text { A background Report drawn up for the Territorial Agenda } \\
2020 \text { (TA2020), defined in } 2011 \text { for the first time the word } \\
\text { Internal Peripheries as "unique types of rural peripheries in } \\
\text { European terms". }\end{array}$ & $\begin{array}{l}\text { (Ministry of } \\
\text { National } \\
\text { Development and } \\
\text { VÁTI Nonprofit } \\
\text { Ltd 2011, p. 57) } \\
\end{array}$ \\
\hline Inner Areas & Similar term & $\begin{array}{l}\text { Within the framework of the Italian National Strategy for Inner } \\
\text { Areas: "The basic idea from which the methodology arises is } \\
\text { that no economic or social development is possible without the } \\
\text { provision of adequate education, health and transport services. } \\
\text { The so-called Services centers offer: an exhaustive range of } \\
\text { secondary schools; at least a 1st level DEA hospital; at least a } \\
\text { "Silver - type" railway station" accordingly to the Italian } \\
\text { Department for Cohesion Policies definition. }\end{array}$ & $\begin{array}{l}\text { (Lucatelli, } \\
\text { Carlucci, \& } \\
\text { Guerrizio 2013, p. } \\
\text { 71; Carrosio, } \\
\text { 2016) }\end{array}$ \\
\hline $\begin{array}{c}\text { Internal } \\
\text { Areas }\end{array}$ & $\begin{array}{l}\text { Synonym (to } \\
\text { Inner Area) }\end{array}$ & $\begin{array}{l}\text { According to the Italian Department of Development and } \\
\text { Economic Cohesion definition, an area is "internal" if it is } \\
\text { located far away from main facilities, while the "poles" are } \\
\text { classified according to the facilities they can offer - a mistaken } \\
\text { English translation from Inner Areas previous definition }\end{array}$ & $\begin{array}{l}\text { (Saccomani } 2014 \\
\text { p. 104) }\end{array}$ \\
\hline Inland Areas & $\begin{array}{l}\text { Synonym (to } \\
\text { Inner Area) }\end{array}$ & $\begin{array}{l}\text { Sharing of main characteristics with Inner Peripheries: } \\
\text { depopulation, less productive agricultural activities, less } \\
\text { services here than in metropolitan cities - a mistaken English } \\
\text { translation from Inner Areas previous definition }\end{array}$ & $\begin{array}{c}\text { (Scrofani \& } \\
\text { Novembre, 2015) }\end{array}$ \\
\hline $\begin{array}{l}\text { Fragile Rural } \\
\quad \text { Areas }\end{array}$ & Similar term & $\begin{array}{l}\text { By a territorial approach, fragile rural areas have three } \\
\text { following main characteristics: lack of coordination of actors, } \\
\text { low level of valorisation of resources and objective disabilities } \\
\text { (e.g. slope, poor soil, relief). Furthermore, these areas have to } \\
\text { deal with disparities in welfare state (services - principle of } \\
\text { equity) and welfare community (services calibrated to specific } \\
\text { advantages and disadvantages) }\end{array}$ & $\begin{array}{l}\text { (Duquenne \& } \\
\text { Hadjou 2010, p. } \\
\text { 14; Osti 2016) }\end{array}$ \\
\hline
\end{tabular}

Source: authors’ elaboration. 
AUTHOR'S CONTRIBUTION

\begin{tabular}{|c|l|c|c|c|c|c|c|}
\hline \multicolumn{1}{|c|}{ ITEM } & $\begin{array}{c}\text { Andrea De } \\
\text { Toni }\end{array}$ & $\begin{array}{c}\text { Matteo } \\
\text { Vizzarri }\end{array}$ & $\begin{array}{c}\text { Bruno } \\
\text { Lasserre }\end{array}$ & $\begin{array}{c}\text { Giovanni } \\
\text { Carrosio }\end{array}$ & $\begin{array}{c}\text { Lorenzo } \\
\text { Sallustio }\end{array}$ & $\begin{array}{c}\text { Paolo Di } \\
\text { Martino }\end{array}$ \\
\hline 1 & Conceptualization & $70 \%$ & $30 \%$ & $0 \%$ & $0 \%$ & $0 \%$ & $0 \%$ \\
\hline 2 & Data curation & $60 \%$ & $40 \%$ & $0 \%$ & $0 \%$ & $0 \%$ & $0 \%$ \\
\hline 3 & Formal analysis & $100 \%$ & $0 \%$ & $0 \%$ & $0 \%$ & $0 \%$ & $0 \%$ \\
\hline 4 & $\begin{array}{l}\text { Funding } \\
\text { acquisition }\end{array}$ & $0 \%$ & $0 \%$ & $0 \%$ & $0 \%$ & $0 \%$ & $0 \%$ \\
\hline 5 & Investigation & $100 \%$ & $0 \%$ & $0 \%$ & $0 \%$ & $0 \%$ & $0 \%$ \\
\hline 6 & Methodology & $60 \%$ & $40 \%$ & $0 \%$ & $0 \%$ & $0 \%$ & $0 \%$ \\
\hline 7 & $\begin{array}{l}\text { Project } \\
\text { administration }\end{array}$ & $0 \%$ & $0 \%$ & $0 \%$ & $0 \%$ & $0 \%$ & $0 \%$ \\
\hline 8 & Resources & $0 \%$ & $0 \%$ & $0 \%$ & $0 \%$ & $0 \%$ & $0 \%$ \\
\hline 9 & Software & $0 \%$ & $0 \%$ & $0 \%$ & $0 \%$ & $0 \%$ & $0 \%$ \\
\hline 10 & Supervision & $0 \%$ & $10 \%$ & $15 \%$ & $10 \%$ & $15 \%$ & $50 \%$ \\
\hline 11 & Validation & $50 \%$ & $50 \%$ & $0 \%$ & $0 \%$ & $0 \%$ & $0 \%$ \\
\hline 12 & Visualization & $50 \%$ & $10 \%$ & $10 \%$ & $10 \%$ & $10 \%$ & $10 \%$ \\
\hline 13 & $\begin{array}{l}\text { Writing - original } \\
\text { draft }\end{array}$ & $50 \%$ & $25 \%$ & $5 \%$ & $5 \%$ & $10 \%$ & $5 \%$ \\
\hline 14 & $\begin{array}{l}\text { Writing - review } \\
\text { \& editing }\end{array}$ & $35 \%$ & $25 \%$ & $10 \%$ & $10 \%$ & $10 \%$ & $10 \%$ \\
\hline
\end{tabular}

Para más información, visitar CRediT: https:/casrai.org/credit/ 